\title{
Contribution of self-efficacy towards career orientation on final-year students
}

\author{
Muh. Ichwan Rachman \\ Department of Psychology \\ Hasanuddin University \\ Makassar, Indonesia \\ muh.ichwan_rachman@yahoo.com
}

\author{
Muhammad Tamar \\ Department of Psychology, \\ Hasanuddin University \\ Makassar, Indonesia
}

\author{
Hillman Wirawan \\ Department of Psychology, Faculty \\ of Medicine \\ Hasanuddin University \\ Makassar, Indonesia
}

\begin{abstract}
Final-year students could be categorized as a young adult age. This age have a developmental task to achieve, which is specificating one's career plan. However, final-year students nowadays were mostly not have any clear career orientation. One of the factor that affecting the individual career orientation level is self-efficacy. By having high self-efficacy, students were expected to plan their career better. The finding of this study shows that about $\mathbf{9 7 \%}$ self-efficacy factor contribute on final-year students career orientation in UNHAS. In other words, the higher self-efficacy is means an inclination in career orientation as well on final-year students. Otherwise, the lower self-efficacy is means a low career orientation on final-year students also.
\end{abstract}

Keywords—career orientation; self-efficacy; final-year students

\section{INTRODUCTION}

Human resources is a crucial asset which is a main factor on determine the success of one nation. However, nowadays value-shifting had occurred where traditional society had turn into modern, manifested by industrial and information advanced. Therefore, in facing these changes, education take an important role on preparing and improve a better human resources in quality. University is the highest level of education on the educational system in Indonesia. Universities hold an important part on preparing a high quality and outstanding students which had a clear future career orientation. Komalasari stated that one of the expected success on students is a success towards their career preparation, whose entering a workplace life and be good worker at their field [1].

One of the key indicator that students are able to plan their future is the occurrence of a developmental career process which is manifested by choosing and planning their career precisely [1]. Based on developmental career theory that were mentioned by Super, students on 18-24 generally are on the second stage, exploration, which individual AT this stage start thinking various work alternative [2]. Super \& Super introduce a career orientation term that can be define as individual preparation on decision making - choosing a career precisely [3]. Thus as a student based on this stage should already have a clear career orientation.

Universitas Hasanuddin (UNHAS) is one of the best university in Indonesia, particularly among East Indonesia region. Early interview was held on five sixth semester students bachelor program (S1) on several faculties in
UNHAS. The result shows that there is a tendency on finalyear students in Unhas still confusing on their career plan after graduate. Final-year students in UNHAS still confuse determine their career path of various options available, students still not deciding whether they want to continue their study further or work after they finish they current study. Hence it can be concluded that finally-year students in Unhas tend to not have a clear career orientation.

Based on some study, one of the predictor that have correlation with career choosing process on individual is selfefficacy [4]. Self-efficacy is one's evaluation towards their own skill or competence to complete a task, achieving goals, and overcome obstacles [5]. The more self-efficacy someone have, the more they have effort on overcoming obstruction to achieve their goal [6]. Thus, individual who have high self-efficacy will be more prepare on deciding a precise career choice for their selves. In other words, if students have belief that their selves can carry out their career choice, then they tend to have a high self-efficacy as well.

Regarding to the early interview also and from several research findings, most students still don't have any preparation on facing workplace, thus causing confusion and anxiety related to it. Helplessness and even anxiety felt are because of individual uncertainty towards their skill on finishing a task [6]. It means that there is also a tendency that final-year students have low self-efficacy related to their preparation on facing workplace. Based on those statements, it can be realized that it is important to conduct a study to find out to what extend the final-year students career preparedness correlated with self-efficacy, by the fact that a prepared career results in a prepared worker to work.

\section{LITERATURE REVIEW}

\section{A. Career Orientation}

Super defines career preparedness as a main concept of career orientation [2]. Career preparedness is defined as individual capability on finishing a task at a certain career developmental stage. [7]. Super stated that career orientation is in line with individual developmental stage generally, which in each stages characterized by a certain task [7]. Therefore, career orientation concept is related to someone's capability on finishing their developmental career task which is corresponding with their developmental career age. 
Educational program such as school and higher education according to Super is a stage where individual gather information about their selves and also the workplace. In this case, through an effective exploration process, individual realize and determine a precise and wise career choice as well as starting to prepare that career plan [3]. Hence, career preparedness generally is strongly related and crucial on exploration stage, where it occurred on individual who is entering a young adult age, which in this case is a student in university. Super then compose a scale to measure career preparedness, this scale is acknowledge as Career Development Inventory (CDI) [7].

Individual career development stated by Super consist of 5 stages: growth, exploration, establishment, maintenance, and disengagement [7]. The exploration stage is strongly related with young adult age where individual start to explore every career choice that is available. Exploration stage consist of 3 sub steps: crystallizing, specifying, and implementing. The specifying here is characterized by individual who already had specify or decide on career choice that their take interest and will experience. Generally in this stage, individual will or just have finish their study so that considered to be ready facing the workplace.

The dimension of career orientation that had been developed by Super consist of two non-cognitive aspect: career planning and also awareness on using own strength for career exploration. Consist as well by two cognitive aspect: world of work information and also decision making ability [7].

Winkel clarified factors that affecting individual career developmental stage into two part [8]. Both cannot be separated as those related each other, which is internal factor and external factor. The internal factors are such as values, intelligence, talent, interest, physical condition and body, and personality. While external factors are society factor, education, family, friendship, also guidance on particular work.

\section{B. Self-Efficacy}

Bandura define self-efficacy as one's belief towards their own capacity to do or behave in certain way, finish task given, and achieve an expected performance [5]. Self-efficacy as a cognitive structure created by cumulative study experience in individual's life that can cause belief or expectation that individual can success on certain task [5]. Self-efficacy is related with particular situation where individual have different self-efficacy degree in different situation.

Individual self-efficacy can be achieved and affected by four main sources, which are mastery experiences, social modeling, social persuasion, and also physical and emotional states [9]. Thus an information about self or one's environment, as well as memory of past will be process in cognitive, determining someone's self-efficacy degree. Luthan et al. stated that individual who has self-efficacy is characterized by: able to determine high target by their selves as well as finishing difficult tasks; feel happy and open on challenges; have high self-motivation, doing various effort to achieve the target; and also persistence in facing every obstacles.
Self-efficacy were consist into three dimension: level, generality and strength [10]. Level dimension refer to someone's self-efficacy degree towards the difficulty level of their task. Generality dimension related to individual mastery towards their task or field of work. As for Strength is the strength of someone's believe towards the capacity that they have.

Super explain that one of the factor that affecting individual's career development is self-concept [2]. Selfconcept is someone's view towards their self and environment. Calhoun \& Acocella stated that individual who has positive self-concept is characterized by having a realistic goal matching with their talent and interest, accept their selves more and as it is, have high probability on achieving their goal and able to plan their selves better [11]. One of the crucial aspect of self-concept is self-efficacy. Self-efficacy define as someone's perception about their physical and psychological capability to overcome obstacles related to enhancement of their life quality [12].

Self-efficacy means believing in self to be successful. Students engaging in career choice for their future will consider their talent and interest tend to able plan and decide a precise choice of career. Students were expected to grow their selfefficacy to have independency on making career decision which they will know what kind of job is suitable for them related to their background education.

\section{METHOD}

Quantitative method with descriptional approach were used in this study, where this research explain self-efficacy contribution on orientation career on final-year students in Hasanuddin University. As for the variable in this research is self-efficacy as independent variable and career orientation as dependent variable.

\section{A. Research Variable}

Independent variable on this research is Self-efficacy. Selfefficacy here means the students belief on their capacity to organize a set of behavior to overcome obstacles on their developmental career process. Self-efficacy were measured by a scale that were adapted before, developed by Luthans et. al, and were based by Self-efficacy theory, introduced by Albert Bandura [6].

Dependent variable on this research is Career orientation. Career orientation as level of individual preparedness on take a precise decision on their career choice, so that directing their behavior to achieve their career. As for the dimensions are: career planning, career exploration, decision making, and world of work information. This variable will be measured by career orientation scale that were adapted by before by Akhbar and based on Career Development Inventory (CDI_college version) [13].

\section{B. Participants}

- The population of this research seventh semester students or more that were assumed as final-year students. Criterion on deciding this students were 
based on career development theory by Super, where final-year students around 18-24 years old should have specification on their career choices. Furthermore, final-year students were assumed as students who will finish their education soon in higher education and entering workplace.

- The population of this research is final-year students at UNHAS, seventh semester or more. The data related to the population based on the criterion shows that there are up to 6858 students in 14 faculties. Deciding on UNHAS students for the population is based on participants availability. Moreover, a beneficial contribution want to be given to UNHAS as a higher education institute.

- Sample is a sub-unit that can be categorized representing the whole research participant. As for the sampling technique on this study is simple random sampling. This technique were used since the population of this research consist of individual groups which have different faculty and a quite numerous data sources. As for the sample criterion on this study is seventh or more semester UNHAS students that were assume as final-year students. The selection of this sample is based that students in seventh semester or more are students who will soon graduate and prepare to enter the workplace. In taking sample from population is by using Slovin formula with 5\% error

\section{Data Collectiong Technique}

Data collecting on this research were using to scales. First is career orientation inventory from scale in Akhbar's research based on career development inventory (CDI_college version) introduced by Super [13]. This scale were composed of orientation career dimension which are: career planning, exploration, decision making, and world of work information.

Second instrument is to measure self-efficacy via questionnaire. This scale were adapted from self-efficacy scale composed by Luthans based on self-efficacy theory by Albert Bandura [15]. This scale consists of 6 item which can measure individual self-efficacy level. Both scale that were used on this research have passed validity and reliability testing by using confirmatory factor analysis (CFA) via LISREL 8.70 software.

\section{Data Analysis}

Data analysis technique on this research is regression analysis. Regression analysis is used to test the self-efficacy contribution on career orientation on final-year students Hasanuddin University by using SPSS v.20. As for the data that were about to process is score from the scale that were transformed to logit value from Winstep software named Rasch Model.

Rasch model is a probabilistic model which means that every individual have different ability level and also item level which produce individual response [16]. Application of this Rasch model is begin by inputting raw score from both scale into the Winstep software. It is called transforming data into logit. In this case, logit value were used in person logit value in person measure table in Winstep application.

\section{RESULT AND DISCUSSION}

Data collecting on this research is begin by preparing and testing the scale that were about to use. Next, data collecting were conducted simultaneously with validity and reliability testing. First, research instrument were given to research participants in some faculties, in total of 150 participant. The 150 temporary participant were tested in reliability and construct by using confirmatory factor analysis (CFA). Data collecting were continue to fulfill the sample target on this research. It was conducted by giving questionnaire, printed or via online form to every faculty in UNHAS. So that finally there were 390 data collected that were the participants of this research which have fulfill the sample criterion. Raw score were that got and data processing is done, for up next conducting hypothesis testing of this research.

\section{A. Result}

This study is aim to find out self-efficacy contribution toward career orientation on final-year students in Hasanuddin University. The total number of this research is 390 students scatter among faculties in UNHS. So that, analysis technique on this research is regression analysis that were used on both research variable, which are self-efficacy as independent variable and career orientation as dependent variable.

The result shows that $R$ value is up to 0,98 , means that there is correlation between independent variable where in this case is self-efficacy, towards dependent variable, career orientation since it fulfill the condition $\mathrm{R}>0,05$. Next, contribution level were showed by $\mathrm{R}$ square value accounted for 0,97 , which next formulated by R square $\mathrm{x} 100 \%$, so the contribution level of self-efficacy towards career orientation final-year students in UNHAS is $97 \%$. Moreover, by the significance value as much as 0,00 shows that the significance value have fulfill the principle $\mathrm{p}<0,05$. Therefore, it can be conclude that $\mathrm{H} 1$ in this research is accepted ( $\mathrm{H} 0$ is refused) which means that there is contribution of self-efficacy towards career orientation on final-year students in UNHAS.

\section{B. Discussion}

Hypothesis testing shows that $\mathrm{Ha}$ is accepted by independent variable contribution's level $\mathrm{R}$ square $=0,97$ and significance degree $\mathrm{p}=0,00(\mathrm{p} \leq 0,05)$ toward dependent variable. This shows that there is significance contribution of self-efficacy towards career orientation of final-year students in UNHAS. Thus the findings of this research proved that one of the factor that affecting career orientation level on final-year students is self-efficacy, by contribution level accounted for $97 \%$.

Final-year students should prepare their selves on continue their career post-graduation, include final-year students in UNHAS. Final-year students in UNHAS as the participants of this research are students which study for seven semester or more. So that, the average age of these participants are 20 years old, which can be categorized as young adults. 
Super explains that one of the factor that affecting career orientation is self-concept. Self-concept is individuals view on their self and environment [2]. According to Calhoun \& Acocella, individual who has positive self concept were characterized by having a realistic goal and matching their talent and interest, can accept self-more and as it is, have a high probability to achieve their goal and can plan their selves to be better [11]. One of the crucial aspects in self-concept is selfefficacy. Self-efficacy can be define as someone's perception on their physical or psychological capacity to overcome obstacles on achieve a better life quality [12]. Therefore, selfefficacy means believe in their selves to be successful. In this case, students as individual who will facing career choices for future will consider their capacity, interest, and personality that they have.

According to this study, shows that one of the factor affecting and contributing on career orientation is self-efficacy. This research shows that high self-efficacy is followed by a high career orientation as well. Otherwise, a low number in self-efficacy affect a low career orientation, indicating that individual need self-efficacy in their selves. Thus it can be stated that final-year students that have high self-efficacy and career orientation can decide a better choice of career. Individual with high self-efficacy when faced by a career preparation process, are able to give effort on knowing their selves better, find out about the jobs and the step to entering those kind of department, and also try to overcome every problem related to the career orientation.

The result of this study is in line with Pinasti's research which find out that there is self-efficacy impact towards student preparedness on finding their career, where the level of contribution from the effect is about $16 \%$, while the rest were affected by other variables such us locus of control, sex, socioeconomic status which is his other variables [17]. Rachmawati also stated that there is a significant correlation between those two variables, where the more self-efficacy a final-year students have, the more is their preparedness on their career [18]. Bandura explained that individual who had high self-efficacy will give more effort to overcome their obstacles and achieve every of their plans and goals, which in this is case is related to career orientation [5]. Therefore, self-efficacy owned by individual will effect on how much is their preparedness on deciding a right career of their selves.

\section{CONCLUSION AND RECOMMENDATION}

\section{A. Conclusion}

- There is self-efficacy contribution towards career orientation on final-year students in Hasanuddin University. The value of self-efficacy's contribution ( $R$ square) towards final-year students career orientation is about $97 \%$, while the rest percentage were affected by other factors. Thus, when students have high selfefficacy, when facing a career preparation process, will do every effort to recognize their selves, find out about their jobs and educational process that should be taken, as well as try to overcome the obstacles related to their goal on career orientation.
- Description of career orientation and self-efficacy on final-year students in UNHAS is divided into three category: low, moderate, high. As for the career orientation and self-efficacy tendency on final-year students in UNHAS is around the moderate category by the amount of $48 \%$ and $43 \%$ each. While in 'high' category of career orientation and self-efficacy is about $26 \%$ and $28 \%$ each, and the rest about $26 \%$ and $29 \%$ is a final-year students in UNHAS which have a 'low' category in career orientation and self-efficacy

\section{B. Recommedation}

- For the further research it is recommended to conduct a study related to career orientation by find out the other factors that may have correlation or have more contribution level. Hence research related on career orientation will make individual to realize more on how crucial a career is, especially for students as a young future generations. Moreover, it is recommended to add more participant's information and control the participants more such as based on culture, region, parents income, and so on.

- For the educational institution, which in this case is in higher education, to compose career development program related to each department, as well as gives socialization to students on how important a career planning and preparation is simultaneously. Furthermore, it is recommended also to increase the self-efficacy capacity on students to help them on deciding their career choice after graduate, for instance by conducting a soft-skill training or personality developmental seminars and so on.

- For the students to constantly have self-efficacy for their life, so that their self-efficacy can continually give effort on every single actions to achieve their goals, by a lot of hard work. Moreover, to every individual who engage in children's nursery, either family, schools, or society to increase the capacity and sensibility on guiding the children's development. Since individual career orientation were start since they were kids.

\section{REFERENCES}

[1] Komalasari, G. Bimbingan Belajar bagi Mahasiswa. Jakarta, 2012.

[2] Super, D. E. “A life-span, life-space approach to career development". Journal of Vocational Behavior, vol. 16, pp. 282-298, 1980.

[3] Super, D. E., \& Super, C. M. Opportunities in Psychology Careers. (B. Camenson, Ed.). United States of America: McGraw-Hill Companies, 2001.

[4] Peterson, S. L., \& DelMas, R. C. "The Component Structure of Career Decision-Making Self-Efficacy for Underprepared College Students." Journal of Career Development, vol.24, pp. 209-225, 1998.

[5] Bandura, A. Self-Efficacy The Exercise of Control. New York: W.H. Freeman and Company, 1997.

[6] Luthans, F., Youssef, C. M., \& Avolio, B. J. Psychological Capital and Beyond, 2015

[7] Sharf, R. S. Applying Career Development Theory to Counseling. USA: Brooks/Cole Publishing Company, 2006.

[8] Winkel, W. S. Psikologi Pengajaran. Yogyakarta: Media Abadi, 2007. 
[9] Feist, J., \& Feist, G. J. Theories of Personality. McGraw-Hill (7th edition). New York: McGraw-Hill Primis, 2008.

[10] Zimmerman, B. J. "Self-Efficacy: An Essential Motive to Learn". Contemporary Educational Psychology, pp. 82-91, 2000.

[11] Calhoun, J. F., \& Acocella, J. R. Psikologi tentang Penyesuaian dan Hubungan Kemanusiaan. Edisi Ketiga. Semarang: IKIP Semarang Press, 2004

[12] Supriyono, W. Psikologi Belajar. Jakarta: PT Rineka Cipta, 2000.

[13] Akhbar, M. N. "Perbedaan Statuses of Identity Ditinjau dari Orientasi Karir Mahasiswa Tingkat Akhir di Universitas Hasanuddin". Bachelor thesis, Hasanuddin University, Makassar, 2016.

[14] Hurlock, E. B. Psikologi Perkembangan: Suatu Pendekatan Sepanjang Ruang Kehidupan ed. 5. Jakarta: Erlangga, 2003.

[15] Luthans, F., Youssef, C. M., \& Avolio, B. J. (2007). Psychological Capital: Developing the Human Competitive Edge. [Online] Available: https://doi.org/10.1093/acprof:oso/9780195187526.001.000

[June, 25.2017]

[16] Sumintono, B., \& Widhiarso, W. Aplikasi Model Rasch Untuk Penelitian Ilmu-ilmu Sosial (Edisi Revisi). Cimahi: Trim Komunikata Publishing House, 2015.

[17] Pinasti, W. "Pengaruh Self-Efficacy, Locus of Control dan Faktor Demografis Terhadap Kematangan Karir Mahasiswa UIN Syarif Hidayatullah Jakarta". Bachelor thesis, Syarif Hidayatullah State Islamic University Jakarta, Jakarta, 2011.

[18] Rachmawati, Y. E. "Hubungan antara Self-Efficacy dengan Kematangan Karir pada Mahasiswa tingkat Awal dan Tingkat Akhir di Universitas Surabaya”. Jurnal Ilmiah Mahasisa Universitas Surabaya, pp. 1-25, 2012. 